\title{
Teacher and Student Questions: A Case Study in Malaysian Secondary School Problem-Based Learning
}

\author{
Tan Yin Peen ${ }^{1} \&$ Mohammad Yusof Arshad ${ }^{1}$ \\ ${ }^{1}$ Faculty of Education, Universiti Teknologi Malaysia, Johor, Malaysia \\ Correspondence: Tan Yin Peen, Faculty of Education, Universiti Teknologi Malaysia, 81310 Johor Bahru, Johor, \\ Malaysia. Tel: 60-17-370-1678. E-mail: yinpeen@gmail.com
}

Received: November 22, 2013

doi:10.5539/ass.v10n4p174
Accepted: December 16, 2013 Online Published: January 26, 2014

URL: http://dx.doi.org/10.5539/ass.v10n4p174

\begin{abstract}
Problem-based learning (PBL) promotes high order questioning and stimulates student thinking, thus playing an important role in preparing students to face real-world challenges. Yet, PBL is an uncommon instructional strategy in Malaysian secondary school science classrooms. Occurrence of questioning in the traditional spoon-feeding classroom is low. Thus, the PBL model adapted from Barrows has been introduced. This article investigates whether PBL is able to promote high order questioning and thinking in the Malaysian science classroom. A PBL class with 1 teacher and 17 students divided into 4 groups was observed, video-and audio-recorded, and the verbatim were analysed. Questions are categorized into high order, low order, eliciting ideas, and evaluating ideas questions. Findings show that the percentage of student questions is $67.9 \%$ while for teacher questions is $32.1 \%$. The amount of student questions per hour is relatively high at 8.2 questions per student. Nearly half of the classroom questions are low order questions $(47.9 \%)$, such as clarification, verification, concept completion, disjunctive, definition, example, quantification, and feature specification questions. High order questions consist of $16.3 \%$, which include causal antecedent, causal consequence, goal orientation, comparison, enablement, and reflective questions. Eliciting ideas questions raised by the teacher cover $8.8 \%$ while evaluating ideas questions by students cover $27.1 \%$. This study shows that the PBL environment promotes active learning, student thinking, and questioning in the Malaysian science classroom. However, student and teacher questions should be enhanced to be at higher order level. Several suggestions to extend low order questions into high order questions are discussed in this paper.
\end{abstract}

Keywords: problem-based learning (PBL), secondary school, teacher question, student question

\section{Introduction}

Generally, teaching practices in Malaysian secondary schools are still using conventional teacher-centred approaches that focus on information purveying, algorithms, as well as drill and practice (Lim, Fatimah, \& Tan, 2002; Maimunah, 2000; Tan \& Arshad, 2011). Teachers perceive their main role as the purveyor of information and instruction, and thus possess high intention to implement teacher-centred learning in their classrooms (Abu Hassan, 2003; Lim, 2007). During lessons, students listen passively to the teacher and questioning only happens occasionally. Students are used to relying on their teachers for all information, explanation, and instructions. As a result, low participation rates, rote learning, and lack of higher-order thinking among the students occur in Malaysian secondary science classrooms.

Teacher questioning is an important and prominent aspect in any classroom. Questioning does not only function to evaluate student understanding, reinforce factual knowledge, and elicit prior knowledge, but also to stimulate student thinking and promote classroom interaction as well as student participation. However, in conventional Malaysian classrooms, the usage of questioning is low and the majority of teacher questions are low order, which do not involve the application of thinking skills. In the study by Zamri and Lim (2011), on average only 24 questions are asked by the teacher per hour, which is significantly lower compared to 69 questions asked by their Western counterparts (Graesser \& Person, 1994). Furthermore, Malaysian teachers are still behind in techniques and skills of asking questions that could promote higher order thinking skills. Previous researches (Supramani, 2006; Tay \& Arshad, 2008; Zamri \& Lim, 2011) reported that the percentage of low order questioning ranges from $72.2 \%$ to $82.4 \%$, which is not a good sign for science classrooms.

Malaysian students are also inactive in asking questions (Nazrulhaiza, 2003). An average of $2.6 \%$ for student 
questioning is reported (Zamri \& Lim, 2011). With teachers holding full authority and control of the classroom lessons, the opportunity for students to put forward their questions is limited. Conventional classrooms in Western countries also reported a low rate of student questions, at an average of 0.11 questions per student per hour (Graesser \& Person, 1994).

As a consequence, many Malaysian students are lacking in thinking skills, and are unable to compete in this globalized era. They face difficulty to adapt to a different learning approach when they leave the school environment. In order to stimulate students' thinking skills as well as other generic skills, problem-based learning (PBL) adapted to local culture has been proposed and introduced in Year 10 chemistry lessons as an instructional method that can promote classroom questioning and increase student participation.

\subsection{Problem-Based Learning (PBL)}

PBL is a pedagogical approach centred on ill-structured real world problems, which encourages the practice of information-gathering, reasoning and problem-solving skills, interpersonal and team working skills, as well as the acquisition of content knowledge, in the process of working out the problem in collaborative groups. The PBL model by Barrows (1992) consists of five major steps: problem presentation, discussion in collaborative team, solution, reflection, and outcome. In PBL, the teacher's role is to facilitate the learning process and provide guidance through questioning and cognitive coaching rather than to provide knowledge. Many studies reported PBL as an effective pedagogical method for holistic learning (Albanese \& Mitchell, 1993; Bilgin, Senocak, \& Sözbilir, 2009; Dochy, Segers, Van den Bossche, \& Gijbels, 2003; Newman, 2003; Norman \& Schmidt, 1992; Vernon \& Blake, 1993).

PBL was first introduced in McMaster University in 1960s. Since then, PBL has been widely adopted throughout higher education and has spread across the globe. PBL was introduced into K-12 education in 1993 in America (Barrows \& Kelson, 1993) and has since being widely adopted in K-12 settings for various subjects, students of various age levels as well as schools in various locations (Hung, Jonassen, \& Liu, 2008). Even though PBL has been practised in some Malaysian tertiary institutions for several years particularly in medical and engineering studies, this approach is still not being widely implemented in Malaysian universities. There is also limited research reported on PBL implementation in Malaysian secondary schools. The majority of Malaysian secondary school students as well as teachers have never come across PBL approach at schools (Faaizah \& Halimah, 2007).

\subsection{Questioning and Problem-Based Learning (PBL)}

Knowledge base is no longer sufficient to excel in this challenging $21^{\text {st }}$ century and the development of students' high order thinking skills are required. Therefore, worldwide science education has been shifted from traditional approaches to active real-world related learning in order to promote student thinking as well as other generic skills. One of the important components in learning is to encourage students to ask good questions. Good questioning has the potential to trigger high order thinking and has been advocated as the main strategy in various active learning approaches.

Questioning is also a frequent strategy used by PBL facilitators to facilitate student learning and enhances discussion (Zhang, Lundeberg, \& Eberhardt, 2011). Students in PBL also play a major role in questioning. Hmelo-Silver and Barrows (2008) reported that the verbal interactions of five second year medical students and one facilitator in PBL shows 68.6 facilitator questions per hour and 18.6 student questions per student per hour. Comparatively, in a conventional classroom, literature reported 69 teacher questions per hour and merely 0.11 questions per student per hour (Graesser \& Person, 1994). It shows a vast difference in the frequencies of student questions. In another study on one-to-one tutoring at college level and $7^{\text {th }}$ grade, Graesser and Person (1994) reported a high frequency of 26.5 student questions per hour in non-PBL context. The increase of student questions per hour may be due to the small ratio of students per teacher.

\subsection{Objective}

Based on the discussion above, the purpose of this article is to investigate the questioning in a PBL science classroom in Malaysia, and whether the content-oriented questions will enhance students' higher order thinking.

Research questions of this study are:

1) What are the frequencies of teacher question and student question per hour?

2) What are the types of teacher question and student question in a PBL classroom? 


\section{Method}

To answer the above questions, a PBL model using FILA-MMS chart (Tan \& Arshad, 2013) is introduced into Year 10 chemistry lessons. A chemistry teacher and his class participated in this study on a voluntary basis. Seventeen students attended the sharing phase session and are divided into four groups. The class activities during sharing phase were observed, audio-recorded, and video-recorded by the researcher.

Verbal interactions are transcribed and analysed using content analysis and constant comparative. Firstly, the transcript is read through, and 'questions' are identified from the verbatim. In this study, interrogative sentences and statements inquiring for information are selected as questions. The questions are then categorized into content oriented questions and non-content oriented questions. As this study focus on the questions that promote thinking and learning related to content, content oriented questions are coded based on the framework used by Hmelo-Silver and Barrows (2008), which is based on Graesser and Person (1994) framework. Other relevant studies on questioning in PBL (Chin, 2006; Zhang, Lundeberg, McConnell, Koehler, \& Eberhardt, 2010) are referenced to assign suitable codes for questions which do not fit into the framework.

Sixteen codes for content-oriented questions are used in this study. The codes are then analysed and categorized into high order questions and low order questions. Direct questions on facts, concepts, and calculations, as well as questions that clarify and verify only involve simple cognitive processes and thus are categorized as low order. Similarly, these questions fall under the knowledge and comprehension category in Bloom's Taxonomy. For questions that involve more complicated cognitive processes such as application and analysis questions are categorized as high order. Six question codes fall under high order while eight fall under low order. Two question codes do not fall into the high-low order dimension, which are eliciting ideas question asked exclusively by the teacher, and evaluating ideas question asked exclusively by the students. The teacher asks eliciting ideas questions to encourage more input and responses from the students. Students ask evaluating ideas questions to check their answer, understanding, and reasoning.

After all questions are coded, their frequencies are counted. Repeated questions are only counted one time. Table 2 in Results and Discussion section shows the list of questions and respective description of each question type.

\section{Results and Discussion}

\subsection{Frequency of Teacher and Student Questions}

High frequency of questions asked is important as questioning invites responses and thus promotes thinking and a two-way communication between the teacher and students. The quality of an active learning lesson will increase with the increment of questioning frequency by both the teacher and students. In this study, the total number of classroom questions is 295 questions with content oriented questions at $81.4 \%$ while non-content oriented coverage is $18.6 \%$ (Figure 1).

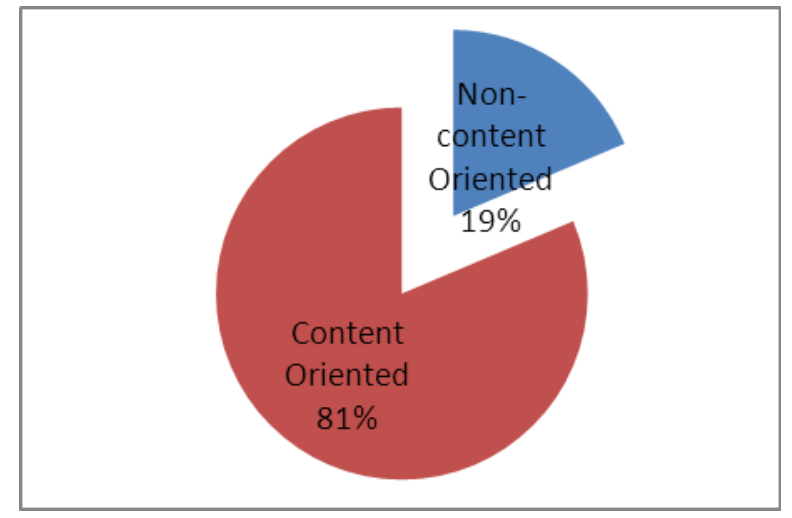

Figure 1. Percentage of content oriented and non-content oriented questions

For content oriented questions, the total number of student questions consists of $67.9 \%$ compared to the teacher questions at $32.1 \%$ (Figure 2). In comparison with 2.6\% (Zamri \& Lim, 2011), this indicates that the PBL environment increases the number of student questions in Malaysia context. 


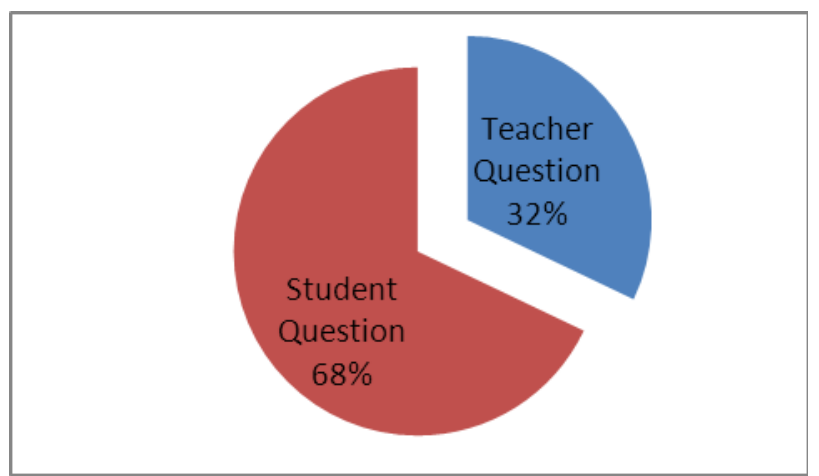

Figure 2. Percentage of teacher and student content oriented questions

Table 1. Number of teacher and student content oriented questions per hour

\begin{tabular}{lll}
\hline & Teacher & Student(s) \\
\hline No. of content oriented questions & 77 questions & 163 questions \\
Length of lesson & 70 minutes & 70 minutes \\
No. of teachers/students & 1 teacher & 17 students \\
No. of questions per hour per person & 66.0 questions per hour & 8.2 questions per student per hour \\
\hline
\end{tabular}

The number of teacher content-oriented questions is 66.0 questions per hour, which is significantly higher than 24 questions in conventional Malaysia classrooms (Zamri \& Lim, 2011) and comparable with the Barrows model of PBL, which has 68.6 facilitator questions per hour (Hmelo-Silver \& Barrows, 2008). The average number of student content-oriented questions is 8.2 questions per student per hour. In comparison with 0.11 questions per student per hour (Graesser \& Person, 1994) for conventional classrooms, our PBL classroom promoted student questioning as much as eighty times higher. This increment is due to the fact that PBL is an active learning method which involves students actively in their own learning. Questioning increases as student participation increases. Students learned on their own and thus raised more questions to verify their understanding and to seek information for the things they do not know or understand.

However, in comparison with the Barrows model of PBL that generates about 18.6 questions per student (Hmelo-Silver \& Barrows, 2008), our PBL classroom falls behind. Due to the large class size in secondary school with only one teacher acting as the facilitator, our PBL implementation is not as effective as implementing in small groups with a facilitator in each group. Secondly, secondary school students are less mature than tertiary level learners and are used to spoon-feeding, thus more time is needed on teacher guidance and explanation when transiting from passive learning to PBL.

\subsection{Types of Teacher and Student Questions}

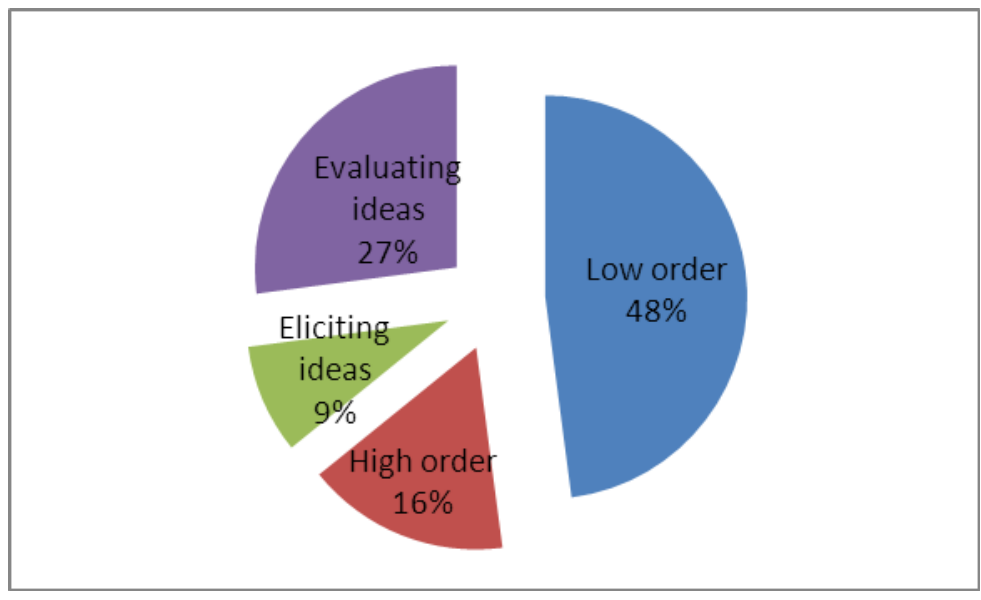

Figure 3. Content oriented questions in PBL classroom 
From this study, four categories of question types in the PBL classroom are found: high order question, low order question, eliciting ideas question and evaluating ideas question. In Figure 3, nearly half of the total classroom questions (46.3\%) are low order questions, such as clarification, verification, concept completion, disjunctive, definition, example, quantification, and feature specification questions. High order questions consist of $15.2 \%$, which include causal antecedent, causal consequence, goal orientation, comparison, enablement, and reflective questions. Eliciting ideas questions raised by the teacher cover $8.8 \%$ while evaluating ideas questions by students cover $27.1 \%$. Table 2 shows the description and examples for each type of question. Both teacher and students are adapting to the transition from conventional teaching to problem-based learning, which can be seen by the increase of teacher and student questions and high student participation. However, many of the questioning still remains at low level. Teacher and students may need more time and practice in their transition to PBL. Secondly, low order questioning might also be due to the exam-oriented system in Malaysia secondary schools. Even in PBL, both the teacher and students are still anxious about exam performance and that students learn the intended factual knowledge and concepts. Thus, students tend to ask more factual questions that seek direct information.

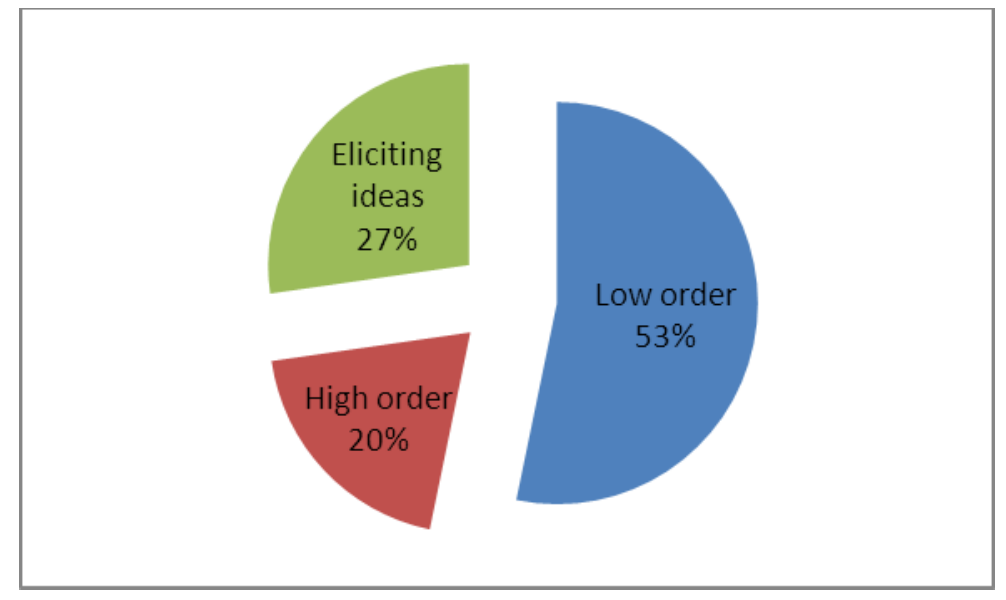

Figure 4. Teacher questions

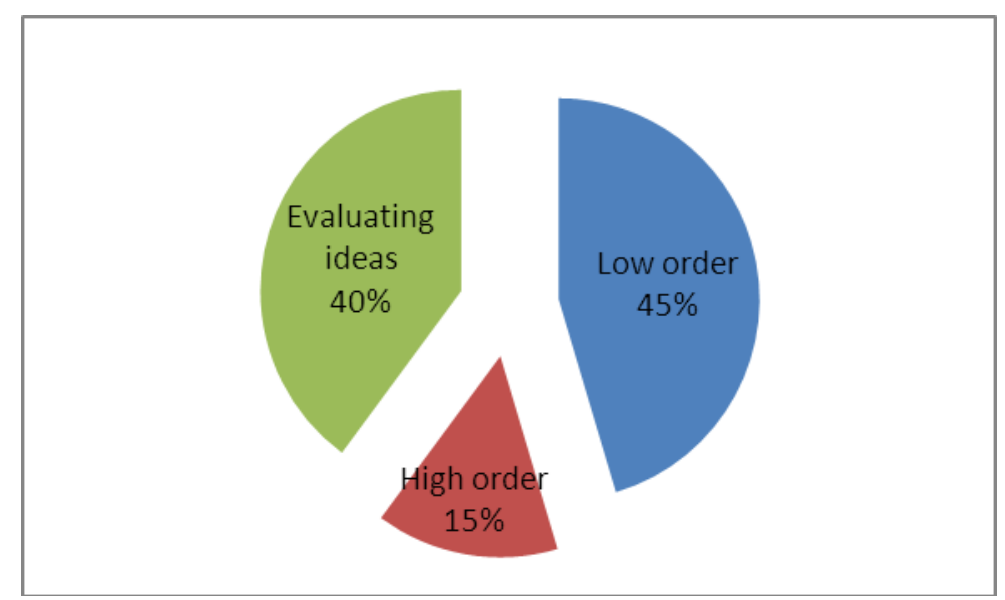

Figure 5. Student questions

Comparison between the categories in teacher questions and student questions (Figure 4 and Figure 5) shows similar pattern with the largest portion of low order questions, smallest portion for high order questions, and intermediate portion for eliciting ideas questions by the teacher and evaluating ideas questions by students. 
Table 2. Coding scheme for different types of questioning

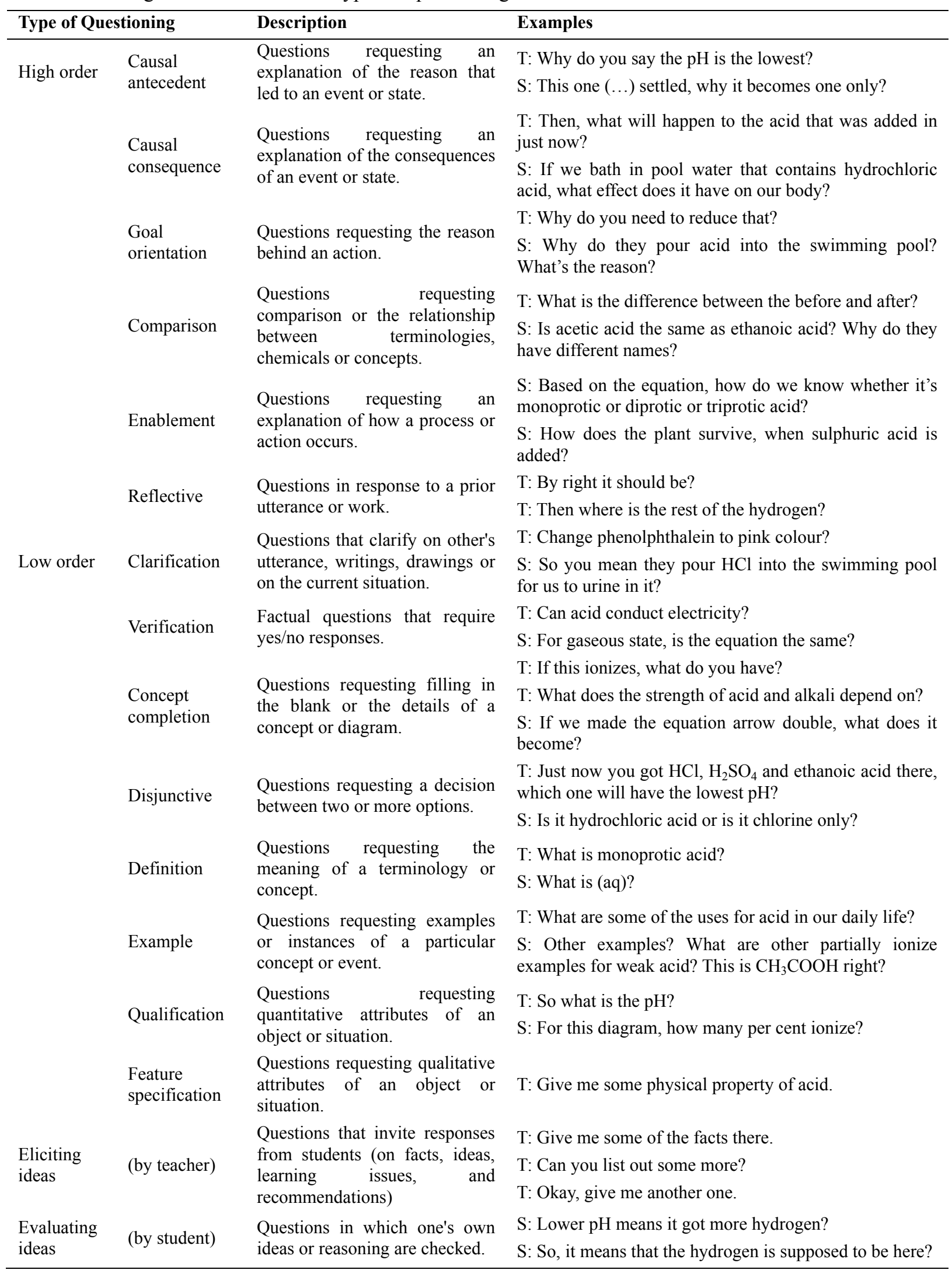

Note: $\mathrm{T}=$ Teacher; $\mathrm{S}=$ Student. 
Table 3. Teacher and student content oriented questions

\begin{tabular}{|c|c|c|c|c|c|c|c|}
\hline \multirow{2}{*}{\multicolumn{2}{|c|}{ Types of Question }} & \multicolumn{3}{|c|}{ Teacher Question } & \multicolumn{3}{|c|}{ Student Question } \\
\hline & & $f$ & TQ \% & Overall\% & $f$ & SQ \% & Overall \% \\
\hline \multirow{7}{*}{$\begin{array}{l}\text { HIGH } \\
\text { ORDER }\end{array}$} & Total & 15 & 19.48 & 6.25 & 24 & 14.72 & 10.00 \\
\hline & Causal antecedent & 5 & 6.10 & 1.95 & 6 & 3.43 & 2.33 \\
\hline & Causal consequence & 1 & 1.22 & 0.39 & 2 & 1.14 & 0.78 \\
\hline & Goal orientation & 2 & 2.44 & 0.78 & 2 & 1.14 & 0.78 \\
\hline & Comparison & 3 & 3.66 & 1.17 & 5 & 2.86 & 1.95 \\
\hline & Enablement & 0 & 0.00 & 0.00 & 9 & 5.14 & 3.50 \\
\hline & Reflective & 4 & 4.88 & 1.56 & 0 & 0.00 & 0.00 \\
\hline \multirow{9}{*}{$\begin{array}{l}\text { LOW } \\
\text { ORDER }\end{array}$} & Total & 41 & 53.25 & 17.08 & 74 & 45.40 & 30.83 \\
\hline & Clarification & 10 & 12.20 & 3.89 & 30 & 17.14 & 11.67 \\
\hline & Verification & 3 & 3.66 & 1.17 & 4 & 2.29 & 1.56 \\
\hline & Concept completion & 14 & 17.07 & 5.45 & 20 & 11.43 & 7.78 \\
\hline & Feature specification & 1 & 1.22 & 0.39 & 0 & 0.00 & 0.00 \\
\hline & Disjunctive & 1 & 1.22 & 0.39 & 5 & 5.14 & 3.50 \\
\hline & Definition & 5 & 6.10 & 1.95 & 7 & 4.00 & 2.72 \\
\hline & Example & 3 & 3.66 & 1.17 & 3 & 1.71 & 1.17 \\
\hline & Quantification & 4 & 4.88 & 1.56 & 5 & 2.86 & 1.95 \\
\hline \multicolumn{2}{|c|}{ ELICITING IDEAS } & 21 & 27.27 & 8.75 & 0 & 0.00 & 0.00 \\
\hline \multicolumn{2}{|c|}{ EVALUATING IDEAS } & 0 & 0.00 & 0.00 & 65 & 39.88 & 27.08 \\
\hline \multicolumn{2}{|c|}{ GRAND TOTAL } & 77 & 100.00 & 32.08 & 163 & 100.00 & 67.92 \\
\hline
\end{tabular}

Table 3 shows that for low order questions, clarification question is the highest, followed by concept completion question, and definition question. Clarification question is a question in response to a previous teacher/student utterance for the purpose of clarifying what the person said. The teacher sometimes used clarification question to indicate a wrong answer or statement from the students. Clarification question is dependent upon the previous response and does not involve high order thinking in this study. To extent clarification question into higher order question, teachers can challenge student to think about their answer with further questions, rather than directly providing them with the correct answer right after the clarification question as shown by the teacher in this study.

Concept completion question serves to purvey, request or check on factual concept understanding. This question has a definite answer and students can answer the question either by rote learning or actually understanding the concept. Higher order thinking can be encourage by further asking students to visualize the concept at the submicroscopic level. In this study, students drew a few submicroscopic diagrams on the board, which aids in their understanding of the relevant concepts. Definition question has the third highest percentage among the low order questions. Teacher asks definition questions to evaluate on student understanding of the terminologies, such as 'monoprotic acid'. Students would ask definition questions when they encounter new terms or symbol, for example 'aq.' which means aqueous.

Following low order questions are eliciting ideas and evaluating ideas questions. Even though these questions covers intermediate portion of teacher and student questions respectively, these questions are actually the highest questions asked (refer Table 3). In PBL, students are expected to find information and learn with their teammates before the classroom session. During the lesson, the teacher did not start off with teaching but with discussion. Thus, eliciting ideas and prompting students to share their group's learning is the first responsibility of the teacher, and thus the highest percentage among teacher questions. Similarly, students learn on their own without the teacher purveying the correct knowledge, thus students have a high tendency to check and evaluate their understanding with the teacher. This is reflected in the highest percentage of evaluating ideas question compared to other student questions.

For high order questions, causal antecedent question has the highest percentage. Causal antecedent question is a question that requests an explanation of the reason for an event or state. In PBL for science, most problem scenarios are design for an explanation of the phenomena. In addition, the 'why' question is asked as a follow-up question to probe further into students' previous answers. This encourages critical and high order thinking. The 
teacher also asks reflective question by tossing a question back to the student or asking a question in response to the student's previous utterance to prompt the student to think and elaborate on his/her statement. Comparison question are also obvious in this study. It promotes students to analyse what they know about the concept and apply to the comparison objects at hand.

Even though high order questions are still low in frequency, the teacher and students did show a practice of asking high order questions. In the long run, with more PBL lessons, teachers and students will show progress in their questioning technique and higher order thinking.

\section{Conclusion and Implication on Science Teaching}

Problem-based learning (PBL) proves to be able to promote teacher and student questioning in Malaysian classroom context during sharing phase, and students are able to adapt to this new learning approach. Thus, this PBL model is recommended to be implemented more widely in secondary school the chemistry subject as well as in other science subjects. However, the ratio of high order questions to low order questions is still low. Teachers need to develop better facilitating and questioning skills. One of the methods is by extending basic low order questions with the 'why', 'how', and 'what if' reflective questions. For example, "why do you say so?", "why is it so?", "how do you do that?", "how does it happen?", "what if that's not ...?", "how about other options...?", etc. These types of questions stimulate students to think critically and creatively. Teachers should continuously reflect on their own questioning practice and make enhancement. Teachers and students who are new to PBL will need some transition time and more PBL experience to complete the shift from passive learning to PBL. Thus, implementation of PBL and the reflection and analyses of the PBL lessons are important for better PBL design and implementation in the future.

\section{Acknowledgements}

The authors would like to express gratitude to the teachers and students involved in this PBL implementation program.

\section{References}

Abu Hassan, K. (2003, October 19-21). Pengajaran-pembelajaran kimia di sekolah menengah: Ke manakah arah tujunya? (Teaching and learning chemistry in secondary school: Where is it heading)? Paper presented at the Seminar Memperkasakan Sistem Pendidikan, Puteri Pan Pasific, Johor Bahru.

Albanese, M. A., \& Mitchell, S. (1993). Problem-Based Learning: A Review of Literature on Its Outcomes and $\begin{array}{lllll}\text { Implementation } & \text { Issues. } & \text { Academic } & \text { Medicine, } & 68(1),\end{array}$ http://dx.doi.org/10.1097/00001888-199301000-00012

Barrows, H. S. (1992). The tutorial process. Springfield: School of Medicine, Southern Illinois University.

Barrows, H. S., \& Kelson, A. (1993). Problem-based learning in secondary education and the problem-based learning institute (Monograph). Southern Illinois University School of Medicine. Springfield, IL.

Bilgin, I., Senocak, E., \& Sözbilir, M. (2009). The effects of problem-based learning instruction on university students' performance of conceptual and qualitative problems in gas concepts. Eurasia Journal of Mathematics, Science \& Technology Education, 5(2), 153-164. Retrieved from http://www.ejmste.com

Chin, C. (2006). Classroom Interaction in Science: Teacher questioning and feedback to students' responses. International Journal of Science Education, $\quad 28(11), \quad$ 1315-1346. http://dx.doi.org/10.1080/09500690600621100

Dochy, F., Segers, M., Van den Bossche, P., \& Gijbels, D. (2003). Effects of problem-based learning: A meta-analysis. Learning and Instruction, 13(5), 533-568. http://dx.doi.org/10.1016/S0959-4752(02)00025-7

Faaizah, S., \& Halimah, B. Z. (2007, November 13-16). C2HADAM: Hybrid PBL multimedia and web based courseware for science. Paper presented at the International Conference on Science \& Mathematics Education (CoSMEd) 2007, SEAMEO RECSAM, Penang, Malaysia.

Graesser, A. C., \& Person, N. K. (1994). Question asking during tutoring. American Educational Research Journal, 31(1), 104-137. http://dx.doi.org/10.3102/00028312031001104

Hmelo-Silver, C. E., \& Barrows, H. S. (2008). Facilitating collaborative knowledge building. Cognition and Instruction, 26(1), 48-94. http://dx.doi.org/10.1080/07370000701798495

Hung, W., Jonassen, D. H., \& Liu, R. (2008). Problem-based learning. In J. M. Spector, J. G. van, M. M. D. Merriënboer, \& M. Driscoll (Eds.), Handbook of Research on Educational Communications and Technology (pp. 485-506). Mahwah, NJ: Erlbaum. 
Lim, C. S., Fatimah, S., \& Tan, S. K. (2002). Cultural influences in teaching and learning of mathematics: Methodological challenges and constraints. In D. Edge, \& B. H. Yeap (Eds.), Mathematics education for a knowledge-based era (Vol. 1, pp. 138-149). Paper presented at the Second East Asia Regional Conference on Mathematics Education and Ninth Southeast Asian Conference on Mathematics Education, National Institute of Education, Nanyang Technological University, Singapore, 27-31 May (Vol. 1, pp. 138-149). Singapore: Association of Mathematics Educators.

Lim, T. C. (2007). Hubungan antara pendekatan pengajaran guru dengan pendekatan pembelajaran pelajar mata pelajaran kimia tingkatan empat (The relationship between teachers' instructional approach and students' learning approach of form four chemistry subject). (Unpublished master's thesis). Universiti Teknologi Malaysia, Johor Bahru, Malaysia.

Newman, M. (2003). A pilot systematic review and meta-analysis on the effectiveness of problem-based learning. Newcastle, UK: Learning \& Teaching Subject Network for Medicine, Dentistry and Veterinary Medicine, Middlesex University.

Norman, G. R., \& Schmidt, H. G. (1992). The psychological basis of problem-based learning: A review of the evidence. Academic Medicine, 67(9), 557-565. Retrieved from http://journals.lww.com/academicmedicine/pages/default.aspx http://dx.doi.org/10.1097/00001888-199209000-00002

Sharifah Maimunah, S. Z. (2000). Current trends and main concerns as regards science curriculum development and implementation in selected states in Asia: Malaysia. In M. Poisson (Ed.), Science education for contemporary society: Problems, issues and dilemmas. Final report of the international workshop on the reform in the teaching of science and technology at primary and secondary level in Asia: Comparative references to Europe. Paper presented at the International Workshop on the Reform in the Teaching of Science and Technology at Primary and Secondary Level in Asia: Comparative References to Europe, Beijing, China, 27-31 March (pp. 39-45). Switzerland: International Bureau of Education.

Supramani, S. (2006). Penyoalan guru: Pemangkin pemikiran aras tinggi murid (Teacher's question: Catalyst of students' higher-order thinking). Jurnal Pendidikan Universiti Teknologi Malaysia, 26, 225-246.

Tan, Y. P., \& Arshad, M. Y. (2011). Problem-based learning: Implementation issues in Malaysia secondary schools science classroom. Paper presented at the International Conference on Science \& Mathematics Education (CoSMEd) 2011, SEAMEO RECSAM, Penang, Malaysia.

Tan, Y. P., \& Arshad, M. Y. (2013). FILA-MMS chart in chemistry PBL lesson: A case study of its implementation during problem analysis. Paper presented at the International Research Symposium on Problem-Based Learning, Putrajaya.

Tay, C. S., \& Arshad, M. Y. (2008). Penyoalan dalam kelas pengajaran sains (Questioning in science teaching classroom). Jurnal Pendidikan Universiti Teknologi Malaysia, 13, 1-14.

Vernon, D. T., \& Blake, R. L. (1993). Does problem-based learning work? A meta-analysis of evaluative research. Academic Medicine, 68(7), 550-563. Retrieved from http://journals.lww.com/academicmedicine/pages/default.aspx http://dx.doi.org/10.1097/00001888-199307000-00015

Zamri, M., \& Lim, N. R. (2011). Kepelbagaian kaedah penyoalan lisan dalam pengajaran guru bahasa melayu: Kaedah pemerhatian (Variety of oral questioning methods in teaching Malay language: observation method). Jurnal Pendidikan Bahasa Melayu; Malay Language Education (MyLEJ), 1(1), 51-65.

Zhang, M., Lundeberg, M., \& Eberhardt, J. (2011). Strategic facilitation of problem-based discussion for teacher professional development. Journal of the Learning Sciences, 20(3), 342-394. http://dx.doi.org/10.1080/10508406.2011.553258

Zhang, M., Lundeberg, M., McConnell, T. J., Koehler, M. J., \& Eberhardt, J. (2010). Using questioning to facilitate discussion of science teaching problems in teacher professional development. Interdisciplinary Journal of Problem-based Learning, 4(1), 5. http://dx.doi.org/10.7771/1541-5015.1097

\section{Copyrights}

Copyright for this article is retained by the author(s), with first publication rights granted to the journal.

This is an open-access article distributed under the terms and conditions of the Creative Commons Attribution license (http://creativecommons.org/licenses/by/3.0/). 